\title{
Metal-ceramic partial fixed dentures: a retrospective study
}

\section{Estudo retrospectivo de próteses parciais fixas metalocerâmicas}

\author{
Fernanda Ferruzzi LIMA ${ }^{1,2}$ iD https://orcid.org/0000-0003-0212-7067 \\ Fabíola Pontes AZEVEDO3 ${ }^{3}$ https://orcid.org/0000-0001-5976-5874 \\ Bárbara Margarido BRONDINO3 ${ }^{3}$ https://orcid.org/0000-0002-5204-9231 \\ Rodrigo Moreira Bringel DA COSTA ${ }^{3}$ iDttps://orcid.org/0000-0002-2056-6787

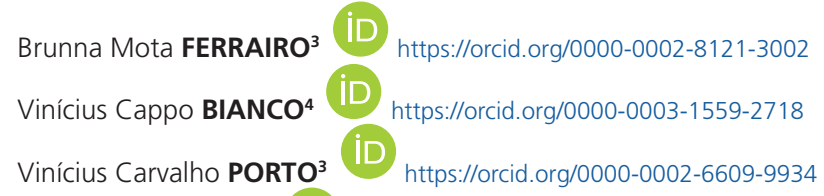 \\ José Henrique RUBO3 ${ }^{\text {iD }}$ https://orcid.org/0000-0003-1595-845X
}

\begin{abstract}
Objective: Metal-ceramic prosthesis are the treatment of choice in oral rehabilitation because of their high survival rates. However, there are few reports in the scientific literature about factors that lead to fractures of metal-ceramic prostheses. The aim of this study was to evaluate whether prostheses units number, abutment type and number, type of the prostheses, prostheses position in the mouth, bruxism and occlusal plaque influence the incidence of fractures in fixed metal-ceramic prostheses. Methods: For this study, 16 patients were selected, totaling 74 metal-ceramic prostheses installed between 2000-2010, with follow up of at least four years. Besides dental history, other information was collected, such as patients' gender and age, prostheses installation date, and the ceramic system used. In case of prostheses fracture, a questionnaire was applied to identify signs of bruxism. A clinical evaluation was done to evaluate the prostheses integrity and opposing dentition characteristics. Success, failure and survival rates were determined. Results: The results showed that the success rate of metal-ceramic prostheses was $87.8 \%$ and the survival rate was $89.1 \%$. In addition, the success rate was independent of patient age, prostheses installation time, number of prosthesis, number of prosthesis' units and abutments. The qualitative variables also did not show significant statistical results between success and failure rates. Conclusion: It was concluded that metal-ceramic prostheses have high success and survival rates, what guarantees longevity and indication of this type of prostheses in daily practice.
\end{abstract}

Indexing terms: Dental prosthesis. Dental restoration failure. Tooth crown.

\section{RESUMO}

Objetivo: As próteses metalocerâmicas apresentam altas taxas de sobrevivência e, por isso, são indicadas para diversos casos em reabilitação oral. Entretanto, na literatura científica, existem poucos relatos clínicos sobre os fatores que levam à fratura dessas 
restaurações. Diante do exposto, o presente estudo teve como objetivo avaliar se a quantidade de elementos que compõem a prótese, se a quantidade de elementos por retentor, se o tipo de prótese e tipo de pilar, bem como sua localização, e o bruxismo, influenciam ou não nas fraturas dessas restaurações indiretas. Métodos: Para isso, selecionaram-se 74 próteses metalocerâmicas, instaladas entre 2000 e 2010 em 16 pacientes, com acompanhamento mínimo de quatro anos. Foram coletadas informações dos pacientes, como: gênero, idade, data da instalação das próteses e cerâmica utilizada. Durante a avaliação clínica, observou-se a integridade da prótese e, em caso de fratura, coletava-se informações sobre a história clínica. As características do dente antagonista também foram avaliadas. Além disso, aplicou-se um questionário, com o intuito de identificar a provável presença de bruxismo. Resultados: Como resultado, tem-se que a taxa de sucesso das próteses metalocerâmicas foi de 87,8\% e, a taxa de sobrevivência, foi de 89,1\%. A taxa de sucesso não teve influência da idade, tempo de instalação, número de próteses na boca, número de elementos ou pilares. Conclusão: Embora pouco frequente, a fratura da cerâmica de cobertura foi a complicação mais comum. As próteses metalocerâmicas possuem altas taxas de sobrevida e de sucesso, o que garante a longevidade e a indicação desse tipo de restauração.

Termos de indexação: Prótese dentária. Falha de restauração dentária. Coroa do dente.

\section{INTRODUCTION}

Metal-ceramic prosthesis are considered the gold standard in oral rehabilitation. They have been used for more than 40 years and present high success rates [1]. Therefore, their use present satisfactory results for patients and dentists alike [2]. Such satisfactory performance is due in part by the use of metal frameworks that promote adequate force distribution during service and resistance to occlusal stress $[1,3,4]$.

Despite of the high success rate of these restorations, fractures are still the most common mechanical complication $[1,4,5]$. Framework fractures are catastrophic in most cases and require replacement by a new prosthesis. Lithium disilicate, alumina and leucite reinforced ceramic are more prone to this type of fracture [1,4-7]. Fractures related to the veneered ceramic influence the prostheses prognostic: if the framework is exposed, a new restoration is needed. Chipping fractures may be solved by polishing and usually do not interfere with function, although esthetics may be compromised. Veneering ceramic fractures are more common when associated to zirconia [8].

Although metal-ceramic have been used in Dentistry for many years, there are still few studies dealing with their long-term survival in randomized controlled clinical trials. Most studies are retrospective or prospective in nature.

This study aimed at clinically investigate the longevity of metal-ceramic prosthesis looking for possible influencing factors that can result in fractures, for a minimum period of 4 years of observation, to contribute to the literature and dentist's decision making when choosing a restorative treatment option.

\section{METHODS}

This study was approved by the Human Research Ethics Committee, Bauru School of Dentistry, University of São Paulo (registration number 617.888, 14/04/2014). All patients treated by the Oral Rehabilitation Program, Graduated Clinic, during the years 2000 to 2010 with metal-ceramic prosthesis were scheduled for clinical evaluation of their restorations.

Forty-nine patients were selected and 16 agreed to participate. These patients presented 74 metal-ceramic prosthesis. A meticulous clinical exam followed by prophylaxis was conducted. Patient file data, like gender, age, day of prostheses installation and ceramic system were recorded. In case of fracture, occlusal contacts were checked with articulating paper and two questionnaires were applied: one for clinical history and one to identify the possibility of bruxism activity.

Metal-ceramic prostheses were evaluated to verify the presence of fractures or cracks and classified in scores, according to the following criteria: 0 - absence of tooth or prostheses; 1 - framework fracture; 2 - veneer ceramic fracture with framework exposure; 3 - broad ceramic fracture with no framework exposure, not reparable by polishing; 4 - subtle veneer chipping reparable by polishing; 5 - ceramic veneer cracks and; 6 - prostheses integrity. Besides, opposing dentition was analyzed and classified as: natural tooth, composite resin or amalgam restored tooth, indirect ceramic restoration, full arch implant restoration and absence of opposing element. Patients that needed new prostheses were referred to Patient Record and Screening Section to be scheduled for new treatment.

Success rates and survival rates were calculated for single unit crowns and fixed partial dentures (FPDs), tooth 
or implant born. Cases where the tooth or prostheses was absent (score 0 ) or where a new prosthesis was necessary (scores 1, 2 or 3) were considered as a failure. Prosthesis with fractures or cracks (scores 4 and 5 ) but still functional were considered as survival. Protheses integrity (score 6) was classified as success.

A descriptive statistical analysis was done for quantitative variables like age, number of prostheses, number of prosthetic units, number of abutments and integrity score, with frequency distribution of qualitative variables (type of prostheses, location, type of abutment, opposing dentition, material, success/failure rate, survival rate, possible bruxism and use of occlusal stabilization splint). Numeric variables correlations were done to observe interaction. To analyze success/failure rate, the correlation of quantitative variables was done after T-test. To analyze the qualitative variables, Fischer test was applied. All statistical tests were done according to $5 \%$ level of significance.

\section{RESULTS}

Seventy-four metal-ceramic restorations stayed in function between 47 and 68 months. The mean age of the patients was 71 years $( \pm 11.3)$. Of the 74 metal-ceramic prosthesis analyzed, $35.1 \%$ were FPDs, $64.8 \%$ were single crowns, $55.4 \%$ were located in the posterior region of the mouth, $32.4 \%$ anterior, $12.1 \%$ had abutments in both anterior and posterior regions, $86.4 \%$ were tooth supported and $13,5 \%$ were implant supported (table 1).

Relative to the opposing dentition, $54 \%$ were higid natural teeth, $28.3 \%$ were ceramic restored teeth, $8.1 \%$ were composite resin or amalgam restored teeth, $8.1 \%$ had no opposing element and only one metal-ceramic prostheses had a full-arch implant prosthesis opposing.

Of the 74 prostheses, nine were absent (score $0)$, two had broad fractures (scores 1, 2 and 3), and were considered as failures. One prostheses scored 4 and another one scored 5 , both of them were considered as survival. Relative to the success rate, $87.8 \%$ scored 6 (integrity) and $89.1 \%$ were classified as survival.

Of all the prosthesis, $32.4 \%$ were in use by patients likely to be bruxers or that have had some episode of bruxism and, from these, only $10.8 \%$ were protected by an stabilization splint (table 1).

Table 2 shows the correlation among quantitative variables (time, number of prostheses, number of units and number of abutments). Values below 0 indicate

Table 1. Frequency distribution of qualitative variables.

\begin{tabular}{|c|c|c|c|}
\hline Variable & Category & Sample (n) & Frequency (\%) \\
\hline \multirow[t]{2}{*}{ Type of prostheses } & Single unit & 26 & 35.14 \\
\hline & FPD & 48 & 64.86 \\
\hline \multirow{3}{*}{ Region } & Anterior and Posterior & 9 & 12.16 \\
\hline & Posterior & 41 & 55.41 \\
\hline & Anterior & 24 & 32.43 \\
\hline \multirow[t]{2}{*}{ Type of abutment } & Tooth & 64 & 86.49 \\
\hline & Implant & 10 & 13.51 \\
\hline \multirow{5}{*}{ Opposing dentition } & Full-arch Implant Prostheses & 1 & 1.35 \\
\hline & Tooth & 40 & 54.05 \\
\hline & Absent & 6 & 8.11 \\
\hline & Ceramic & 21 & 28.38 \\
\hline & Restoration & 6 & 8.11 \\
\hline Material & Metal ceramic & 74 & 100 \\
\hline \multirow{3}{*}{ Success } & Success & 65 & 87.84 \\
\hline & Failure & 8 & 10.81 \\
\hline & Survival & 1 & 1.35 \\
\hline \multirow{3}{*}{ Bruxism } & Possible & 24 & 32.43 \\
\hline & Absent & 49 & 66.22 \\
\hline & Probable & 1 & 1.35 \\
\hline \multirow[t]{2}{*}{ Occlusal splint } & No & 66 & 89.19 \\
\hline & Yes & 8 & 10.81 \\
\hline
\end{tabular}


Table 2. Correlation of numeric variables.

\begin{tabular}{|c|c|c|c|c|c|c|}
\hline & Age & Number of prostheses & Number of units & Number of abutments & Time & Score \\
\hline \multirow[t]{2}{*}{ Age } & & .5974 & -.3392 & -.2675 & .0426 & -.0425 \\
\hline & & $\mathrm{p}=.000$ & $p=.003$ & $p=0.21$ & $p=0.719$ & $p=0.719$ \\
\hline Number of prostheses & $\mathrm{p}=.000$ & & $\mathrm{p}=.000$ & $p=.000$ & $p=.264$ & $\mathrm{p}=.972$ \\
\hline Number of units & -.3392 & -.5286 & & .5545 & .1150 & -.0361 \\
\hline Number of abutments & $\mathrm{p}=.021$ & $\mathrm{p}=.000$ & $\mathrm{p}=.000$ & & $\mathrm{p}=.496$ & $p=0.78$ \\
\hline \multirow[t]{2}{*}{ Time } & .0426 & .1315 & .1150 & .0803 & & -.0270 \\
\hline & $\mathrm{p}=.719$ & $\mathrm{p}=.264$ & $p=.329$ & $\mathrm{p}=.496$ & & $\mathrm{p}=.819$ \\
\hline Score & -.0425 & -.0041 & -.0361 & -.2060 & -.0270 & \\
\hline
\end{tabular}

negative correlation. For the variables "age vs. number of prostheses" and "number of units vs. number of abutments", the correlations were positive and statistically significant $(p<0.05)$, which means that as older the patient, as larger the number of prosthesis. Also, as larger the number of units, as larger the number of abutments.

For the correlation "success or failure" and quantitative variables (age, number of prosthesis, number of units, number of abutments and time) the T-test was done and no correlation was statistically significant $(p=069)$. For the correlation between success or failure" and the qualitative variables (gender, type of prosthesis, type of abutment, possible bruxism and use of stabilization splint), Fischer test was applied with no statistically significant differences observed. For the correlation between region of the mouth and opposing dentition with prostheses success, Qui-square test was done and no statistically significant differences were detected for region $(p=0.88)$ or opposing dentition ( $p=0.674)$.

\section{DISCUSSION}

This retrospective study have shown that fixed metal-ceramic prosthesis present a high success rate $(87.8 \%)$ and survival rate $(89.1 \%)$ in the four-year followup, what is in accordance with previous studies $[1,4,9,10]$.

Sailer et al. [10], in a systematic review comparing survival rates and complications among implant-supported FPDs with metal or zirconia frameworks, found success and survival rates of $84.9 \%$ e $98.7 \%$ respectively, for metal-ceramic prosthesis in 5-year follow-up. Additionally, Sailer et al. [1] observed a survival rate of $95.7 \%$ for tooth supported metal-ceramic single crowns. Pjetursson et al. [4] also observed similar results for multiple tooth-supported metal-ceramic FPDs with a $94.4 \%$ survival rate in a period of 5 years.

Relative to the failure of metal-ceramic FDPs, there was a predominance of score $0(81.8 \%)$ over scores $2(9.05 \%)$ and $3(9.05 \%)$, suggesting a greater influence of biological complications. Among these, loss of vitality, fracture, secondary caries and periodontal disease are most frequently reported in the literature $[1,4]$. Although the reasons for the absence of teeth and prosthesis were not reported in the present study because of lack of registered data, it is possible that the before mentioned factors have had substantial influence in these results.

Ceramic fracture was the most frequent complication, causing the failure of two FDPs (scores 2 and 3). Fracture was also involved in two other prosthesis considered as survivals (scores 4 and 5 ). This result is in accordance with the findings of Sailer et al. [1], where a larger frequency of ceramic chipping was observed with an incidence of $2.6 \%$ in 5 years.

Similarly, Heintze et al. [9] also observed veneer ceramic fracture as the most common complication, mainly small chippings, which ultimately needed only polishing of the restoration. The frequency of larger and more severe chipping in its turn was lower, with statistically significant difference. Veneer ceramic chipping can be caused by inadequate ceramic thickness, as well as by improper framework design with lack of interproximal support, what increases the incidence of such event [9]. 
Although simple and severe complications have presented similar frequencies, it is possible that the frequency of simple complications (score 5), like small cracks, be higher. Nevertheless, according to a previous study, they cannot be detected only by visual inspection during clinical exam [9].

The type of abutment (tooth or implant) did not influence the success rate $(p=1,00)$. However, the existence of an expressive difference between the frequency of toothsupported prosthesis $(86,49 \%)$ and implant-supported prosthesis $(13,51 \%)$ may have influenced our results. Similarly, the type of prostheses, single crown or FPD, did not influenced the results $(p=1,00)$, indicating that type of abutment as well as number of units were not decisive for failure.

Although more posterior prosthesis has been observed $(55,4 \%)$ relative to anterior $(32,4 \%)$, there was not a statistically significant difference regarding success of the treatment $(p=0,889)$. The same pattern was observed by De Backer et al. [11], in a retrospective study with a 20year follow-up. This behavior was also observed by Sailer et al. [1], comparing survival of metal-ceramic single crowns cemented on teeth, where no correlation was found according to region of the mouth, survival and success of the restorations.

Metal ceramic FDPs present high success and survival rates, what makes them the gold standard, the treatment of choice for prosthetic treatments, according to the literature.

\section{CONCLUSION}

Metal ceramic FDPs presented high success and survival rates. Factors like region of the mouth, type of prostheses and type of abutment did not influenced treatment success. Although not much frequent, veneer ceramic fracture was the most clinically relevant complication.

\section{Collaborators}

FF LIMA: Conceptualization, data curation and methodology. FP AZEVEDO: Methodology. BM BRONDINO: Writing original draft and writing-review \& editing. RMB COSTA: Writing original draft. BM FERRAIRO: Data curation and investigation. VC BIANCO: Data curation. VC PORTO: Supervision. JH RUBO: Conceptualization, project administration, supervision and writing-review \& editing.

\section{REFERENCES}

1. Sailer I, Makarov NA, Thoma DS, Zwahlen M, Pjetursson BE. All-ceramic or metal-ceramic tooth-supported fixed dental prostheses (FDPs)? A systematic review of the survival and complication rates. Part I: Single crowns (SCs). DEMAEP. 2015;31(6):603-23. http://dx.doi.org/10.1016/j.dental.2015. 02.011

2. Raza MFF, M.; Akram, S. Complications and their severity in patients of conventional metal ceramic fixed dental prosthesis: a clinical study. PODJ. 2015;35(1):155-8.

3. Kina S. Cerâmicas dentárias. Dent Press de Estétic. 2005;2(2):112-28.

4. Pjetursson BE, Sailer I, Makarov NA, Zwahlen M, Thoma DS. All-ceramic or metal-ceramic tooth-supported fixed dental prostheses (FDPs)? A systematic review of the survival and complication rates. Part II: Multiple-unit FDPs. DEMAEP. 2015; 31(6):624-39. http://dx.doi.org/10.1016/j. dental.2015.02.013

5. Pjetursson BE, Sailer I, Zwahlen M, Hammerle $\mathrm{CH}$. A systematic review of the survival and complication rates of all-ceramic and metal-ceramic reconstructions after an observation period of at least 3 years. Part I: Single crowns. Clin Oral Implants Res. 2007;18 Suppl 3:73-85. http://dx.doi.org/10.1111/j.16000501.2007.01467.x

6. Sailer I, Pjetursson BE, Zwahlen M, Hammerle CH. A systematic review of the survival and complication rates of all-ceramic and metal-ceramic reconstructions after an observation period of at least 3 years. Part II: Fixed dental prostheses. Clin Oral Implants Res. 2007;18 Suppl 3:86-96. http://dx.doi. org/10.1111/j.1600-0501.2007.01468.x

7. Wang X, Fan D, Swain MV, Zhao K. A systematic review of allceramic crowns: clinical fracture rates in relation to restored tooth type. Int J Prosthodont. 2012;25(5):441-50.

8. Ortorp A, Kihl ML, Carlsson GE. A 5-year retrospective study of survival of zirconia single crowns fitted in a private clinical setting. Int J Dent. 2012;40(6):527-30.

9. Heintze SD, Rousson V. Survival of zirconia- and metalsupported fixed dental prostheses: a systematic review. Int J Prosthodont. 2010;23(6):493-502.

10. Sailer I, Strasding M, Valente NA, Zwahlen M, Liu S, Pjetursson $B E$. A systematic review of the survival and complication rates of zirconia-ceramic and metal-ceramic multiple-unit fixed dental prostheses. Clin Oral Implants Res. 2018;29 Suppl 16:184-98. http://dx.doi.org/10.1111/clr.13306

11. De Backer $H$, Van Maele G, De Moor N, Van den BL, De Boever J. A 20-year retrospective survival study of fixed partial dentures. Int J Prosthodont. 2006;19(2):143-53.

Received on: 6/6/2019 Final version resubmitted on: 17/10/2019 Approved on: 31/10/2019 